\title{
Human-Natural System Sustainability in Buenos Aires Province, Argentina
}

\author{
Silvia Diana Matteucci ${ }^{1}$ \\ ${ }^{1}$ National Research Council of Argentina, Landscape Ecology and Environment Team, Buenos Aires University, \\ Argentina \\ Correspondence: Silvia Diana Matteucci, GEPAMA, Buenos Aires University, Buenos Aires City, C1428EGA, \\ Argentina. Tel: 54-11-4552-9636. E-mail: sdmatteucci@conicet.gov.ar \& smatt03@gmail.com
}

Received: September 11, 2012 Accepted: September 19, 2012 Online Published: September 24, 2012

doi:10.5539/jgg.v4n4p76 URL: http://dx.doi.org/10.5539/jgg.v4n4p76

\begin{abstract}
The Argentinean Pampean plain has been under agriculture and farming since colonial times. Its loessic soils have the highest production capacity in Argentina, in spite of which it is suffering extensive land use change due to urban expansion. The aim of this work is to evaluate the consequences of urban expansion on environmental conditions, including population welfare. An integrated analysis was carried out based on sets of ecological, physical support of production, land use and social condition variables. We hypothesize that land use change may generate unstable situations that negatively affect the natural-social system resilience, with the consequent loss of sustainability, and that this effect is perceived through the consistency among the factors on which the system resilience depends. The prediction is that a poor association between physical support and land use entails a misuse of resources that will be reflected on the social conditions.

The results show that the prediction is fulfilled in some cases but not in others. Four combinations of adjustment between physical support and land use, and their consequence on social conditions were found. Land use is reflected on the social conditions, either because of social welfare as a consequence of proper land use, or because of the adverse social conditions associated to the improper allocation of land to uses for which it is not suitable. Alternatively, either social indicators of poverty prevail despite proper land use, or social welfare occurs in the presence of improper land use. In both cases, land use is not reflected in social conditions. The consequences of the four conditions on land management planning are discussed.
\end{abstract}

Keywords: land use change, urban expansion, resilience, Procrustes analysis

\section{Introduction}

The Pampean plain, under agricultural and cattle ranching production since the colonial period, has been changing significantly as a result of urban expansion over lands of high agricultural and ranching land use capacity (Morello et al., 2003). The most productive agricultural lands of Argentina are found on this plain. It is one of the five extensive loess areas of the world, and it has enough rainfall to produce sustained high yields of soybeans, wheat, sunflower and corn, representing $52 \%$ of the national agricultural production value, according to the 2002 Agricultural and Livestock Census (INDEC, 2006). The climate is temperate, milder than in other regions at the same latitude due to the temperature moderating effect of the ocean; thus snowfall is absent, and diurnal and seasonal temperature amplitudes are reduced $\left(10^{\circ}-12^{\circ}\right.$ Celsius between the coldest and the warmest months). This together with evenly distributed annual rainfall allows for year-round cropping. The native grassland has been almost completely converted to croplands, and only a few and isolated patches of the native grassland (flechillar) remain. Buenos Aires city is located on the north-east coast of the pampean plain. Urban growth, which began as a process of metropolization in 1940 and was boosted by exurbanization since 1990, has triggered a conflict of interests with agriculture, and considerable extensions of farmland have been irreversibly lost (Matteucci y Morello, 2009).

The main idea of complex system research is that the impact chains produced by urban activities, which are concentrated in the periurban area, cannot be studied individually, link by link (World Resources Institute, 1996), and cannot be limited to urban and periurban areas. The context should be considered, since the urban border is dynamic and expanding with a delayed manifestation of its visible effects. Even before the definite impermeabilization is produced, some changes will occur, setting the scene for this final and irreversible 
transformation. Air and water contamination, the loss of native diversity, the alteration of the biogeochemical cycles, the variation of the primary production rates, the alteration of regimes of natural disturbances, are all processes which begin to occur much earlier than urban densification and are not perceived until it is too late.

Complex systems such as the Argentinean Pampean plain require a simultaneous analysis of the human and natural subsystems in order to understand the interactions between them, by means of the integration of ecological and social variables (Lockaby et al., 2005; Schmitz et al., 2003; Wear \& Boldstad, 1998). The aim of this work is to elucidate the way and extent to which urban expansion modifies the environmental conditions, including the population welfare. For this purpose, an integrated analysis was carried out based on sets of ecological, physical support of production, land use and social conditions variables. We hypothesize that land use change may generate unstable situations that affect the resilience of the human-natural system (Holling, 1973; Gunderson \& Holling, 2002) with the consequent loss of sustainability, and that this effect is perceived through the consistency among the factors on which the system resilience depends. The prediction is that a poor association between physical support and land use entails a misuse of resources that is reflected on the social conditions.

\subsection{Study Area}

The study area is located in Buenos Aires province, between $33^{\circ} 26^{\prime}$ and $38^{\circ} 25^{\prime} \mathrm{S}$, and $56^{\circ} 67^{\prime}$ and $61^{\circ} 36^{\prime} \mathrm{W}$, with a total area of $97,713 \mathrm{~km}^{2}$ (Figure 1). This zone presents more risk of urban encroachment due to its proximity to large cities such as Buenos Aires, La Plata and Mar del Plata, and to the recent development of highways.

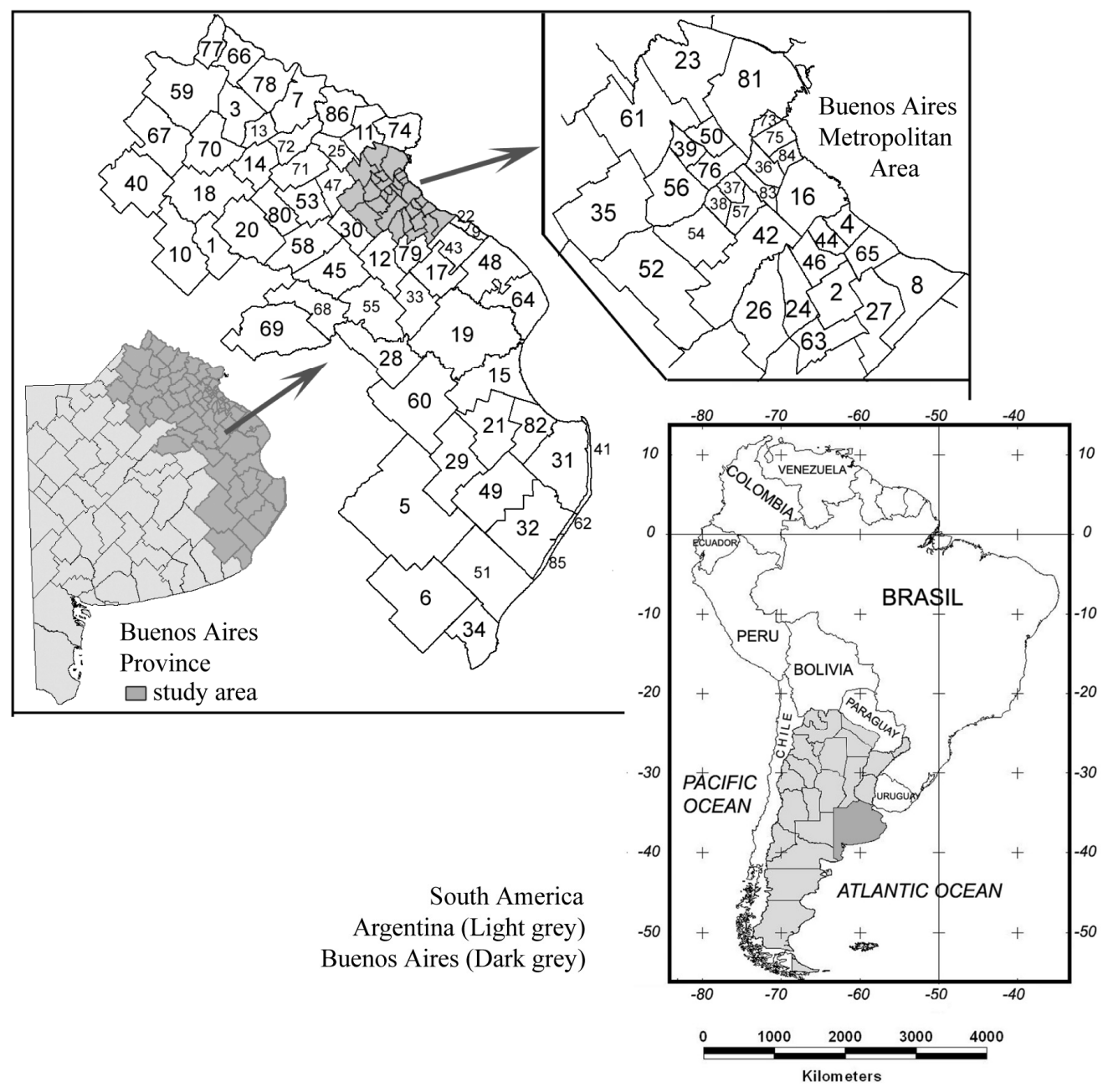

Figure 1. Study area (The numbers identify the counties)

The area is located within the Pampa Ecoregion and includes two subregions which differ in geology and geomorphology: the Rolling Pampa and part of the Flooding Pampa. The Rolling Pampa occupies a sedimentary 
basin over a crystalline plinth folded in a sinusoidal way in which the plain rises to the North and Southeast and lowers in the center. During the Quaternary Age, a $200 \mathrm{~m}$ deep layer of sediments deposited over the crystalline plinth, with strata of diverse ages that can be observed in the gully walls of the La Plata river. The last stratum, the Holocene, is the loessic one, and constitutes the parental material of most agricultural soils in Buenos Aires (SAGyP-INTA, 1989). Its topography is characterized by soft, wide undulations separated by talwegs and some rivers and creeks. At present, the predominant activity is agriculture. The Flooding Pampa is formed largely by a low plain and its main activity is cattle ranching. It is covered by natural grasslands in $80 \%$ of its extension. Its topography is flat and lacks a well developed drainage system. This fact together with the low hydraulic conductivity of soils result in the occurrence of floods in late winter and spring, while droughts are frequent in summer.

\section{Methods}

The work was developed through several stages. Firstly, the study area was divided into zones according to their predominant land use type, then associations among factor sets were identified, and finally the causes for lack or little concordance between factor sets affecting production and social welfare were determined.

\subsection{Variable Sets}

The sampling unit was the county, which is the smallest autarkical jurisdiction in which economic (land use) and social variables are assessed and reported. Natural variables were adjusted to political boundaries by fitting the land cover map, topography and soil to the county maps. The advantage of expressing the results at a relatively autarkical political division is that they can be applied by local governments for land use planning and management, and also combined for use at higher levels of political organization.

Variable sets include the following: the ecological, the physical support of agricultural production (productive capabilities of soils and topography), the economic and the social sets (Table 1). All four variable sets are independent since they come from different sources.

\subsubsection{Ecological Variables}

The ecological variables are the landscape metrics: proportion of total area occupied by each land cover type and its spatial configuration. Land cover is the observed biophysical cover on the earth surface, while land use refers to productive activities, including type of activity, technology, land ownership, production strategies, among other (Di Georgio \& Jansen, 2000). Land cover maps are obtained by means of processing aerial photos or satellite images, while land use maps include census data.

The land cover map was obtained through the processing of 10 satellite images that cover the study area. The Landsat 7 ETM images from the 2002-2003 summer were projected in the Posgar 94 coordinates system. Each image was automatically clasiffied into 16 classes and was filtered with a $3 \times 3$ kernel in order to remove isolated pixels. Then, the images were reclassified into 7 classes (water surface, wetlands, high woody vegetation, dense herbaceous vegetation, dispersed herbaceous vegetation, bare soil, impervious surface). Herbaceous vegetation included natural cropping and grasslands, and woody vegetation included forest plantations and natural woods. The correspondence between land cover types and the 16 categories of the automatic classification was established by field survey. By means of a process of aggregation, the resolution was reduced from the original $25 \times 25 \mathrm{~m}$ to $125 \times 125 \mathrm{~m}$ to facilitate land metrics calculation, and to remove patches under $1 \mathrm{ha}$.

County maps in vectorial format provided by the INDEC were projected to Posgar 94 coordinates and converted to raster format. Raster maps of cover types of each county were obtained by image intersection with county maps. For those counties displayed in two images, mosaics were made before clipping.

Landscape metrics were calculated on land cover maps with the patch grid module of Patch Analyst (Elkie et al., 1999). A correlation analysis was performed, and only non-correlated metrics which showed discriminatory and explanatory capacities in the discriminant analysis were used (Table 1).

\subsubsection{Physical Support of Production}

The information on soils was obtained from the Soils Atlas of the Argentine Republic (Maccarini \& Baleani, 1995). Two thematic layers were extracted: topographic units and cartographic productivity index. Each layer was clipped using the study area limits in order to simplify maps and tables handling. The 26 topographic position categories in the Atlas were gathered into six types: plains, hillocks, alluvial plains, flooding lowlands, slopes, and non-productive lands. The percentage of area occupied by each topographic type was calculated for each county (Table 1). 
Table 1. List of variables

\begin{tabular}{ll}
\hline LANDSCAPE: landscape metrics \\
DP & Patch Density \\
MPS & Mean Patch Size \\
ED & Edge Density \\
AWMSI & Area-Weighted Mean Shape Index \\
$\%$ Agua & Water surface cover \\
$\% \mathrm{H}$ & Wetlands cover \\
$\% \mathrm{~B}$ & Woody vegetation cover \\
$\% \mathrm{VB}$ & Herbaceous vegetation cover \\
$\% \mathrm{U}$ & Impervious surface cover \\
\hline
\end{tabular}

SOIL: Cartographical Productivity Index (\% of the county area)

Ipc0-30 Very low productivity capacity

Ipc31-50 Low productivity capacity

Ipc51-70 Medium productivity capacity

Ipc71-95 High productivitycapacity

\section{TOPOGRAPHY (percentage of county area)}

TIM Unproductive lands: sandbanks, lakes, marshlands, etc

TIN Flooded lands

LO Hillocks

PEN Slopes

PLA Plains

PAL Alluvial plains

\section{LAND USE}

NEAP Total number of farms

PI Percentage of the county area under agricultural use

PPN Percentage of the county area under natural grasslands

TPEAP EAP mean size per county

PFOR Percentage of the county area under forestry (forests and/or woodlands)

$\%$ cult Percentage of the county area under annual and perennial crops

$\%$ PAST Percentage of the county area with planted pastures

$\%$ forraj Percentage of the county area under annual and perennial fodder crops

\section{SOCIAL VARIABLES}

Var\% Percentage of population variation between 1991 and 2001

Dpob Population density (inhabitants per $\mathrm{km}^{2}$ )

NBI Population with unsatisfied basic needs as percentage of total population

\%Anal Illiterate Population 10 years old or older as percentage of total population

OS Population in households with no social security income as percentage of total population

VD Population living in houses with some deficiency as percentage of total population

ED Population 10-14 years old never attending school as percentage of total population

JU Population 70 years old or older not receiving retirement as percentage of total population

PobRur Percentage of rural population 
Deficient housing: shacks, huts, rental rooms, guesthouse or hotel rooms, premises not built for dwelling purposes, mobile homes and houses with no water provision through a pipe system inside the house, or no flushing toilet, or dirt floors or floors made of materials other than ceramic tiles, mosaic tiles, marble, wood or carpet, concrete or fixed bricks.

The cartographic productivity index (IPc) is an indicator of the predominant productive capacity (potential productivity) in each soil cartographic unit. This index takes into consideration climate, and soil variables (drainage, depth, texture, salinity, alkalinity, organic matter, cationic exchange capacity and erosion). It is valid only within the region for which it was assessed because it shows the fraction of the maximum yield potential for the most common crops adapted to the local conditions and under a given level of management. The higher the value of the cartographic productivity index, the nearer the agricultural production capacity of such land unit to the potential value. The continuous series of whole values represented in the map was classified into 4 classes: 0-30; 31-50; 51-70; 71-95. For each county, the fraction of its territory occupied by each class of IPc was calculated (Table 1).

\subsubsection{Land Use Variables}

The data source for land use was obtained through the last National Agriculture and Livestock Census (INDEC, 2006). Values per county were expressed as the percentage of its territory occupied by each land use, and number and average size of farms (Table 1).

\subsubsection{Social Variables}

Those variables considered as indicators of the population social conditions were selected. They include demographic data and indicators of life quality (Table 1). Data was obtained from the 2001 National Population and Housing Census (INDEC, 2001).

\subsection{Statistical Procedures}

Counties were classified into productive zones by means of cluster analysis, with squared euclidean distance as similarity measure, standarized variables, and the complete linkage as amalgamation rule. Three spatial models with alternate sets of land use and production physical support variables were obtained. These variables were chosen because they constitute the reference point for the other variables, since it is an area naturally suitable for agriculture and ranching, which have been the traditional economic activities. The best classification was chosen through discriminant analysis.

The discriminant function analysis is applied to nominal dependent and numerical independent variables, and allows to: 1) asses an a priori classification of counties; 2) maximize the differences among groups in a bi- or multi-dimensional space; 3) assign new counties to the system using the resulting canonical functions; 4) determine the variables that carry the most weight in the canonical function. The last point bears significance, since it allows the reduction of the variable number to be included in the canonical function by selecting those which contribute maximally to group separation.

The three classifications (zonifications) obtained from the cluster analysis were the a priori models for the discriminant analysis. The a posteriori classification was based on the landscape metrics calculated from the land cover map. First, the landscape metrics that fit into the model for each of the a priori classifications were selected from the 56 initial dependent variables through a stepwise process. Covariance matrix homogeneity was accepted for the productive zones. The selected variables (46 in total) were used to find the discriminant function and to estimate the classification error for each a priori classification.

The presence of significant differences between production zones in the selected classification was determined through univariate analysis of variance and Tukey (Honest Significant Difference test). The HSD technique was chosen over the Fischer test because it is more conservative and allows comparing six means simultaneously, each with different number of cases. The descriptions of the productive zones are based on those variables which showed significant differences among two or more zones.

The selected zonification was used to assess the consensus among variable sets through the Generalized Procrustes analysis, which is a mathematical technique for comparing two or more data sets (Gower, 1975; Jackson \& Harvey, 1993; King \& Jackson, 1999). Each data set is represented by a matrix and constitutes a hyperdimensional space with as many dimensions as variables, and as many cases as classified units (counties). By means of standarization, traslation and orthogonal rotation, the Procrustes model adjusts the resulting configurations of each variable set, minimizing the sum of squared deviations among equivalent cases (counties) in both configurations without modifying the distance relations among counties (intragroup). The requirement is that the adjusted matrices have equal number of lines (counties), but they may have different number of columns (variables). The Generalized 
Procrustes analysis calculates the residual vector of the deviations among cases for each axis. This vector is a measure for the adjustment degree among the spatial configurations; the lower the residual intragroup sum of squares, the better the adjustment. This value is converted into a consensus measure which takes into account the residual of all the axes. Consensus is expressed as the intragroup sum of squares of the consensus divided by the total sum of squares (consensus plus residual) multiplied by 100; the higher the percentage, the higher the degree of association between variable sets.

The Generalized Procrustes analysis was performed with the Infostat software (INFOSTAT, 2004) for the five sets together (Table 1), and for pairs of variable sets in order to identify the sets with the highest association and to generate hypotheses related to the similarities or differences found. The county situation diagnosis was determined through calculating the consensus between production physical support and land use, and between land use and the social variables, for each productive zone separately to detect differences among counties within each zone. The physical support of agriculture and livestock production is the combination of the soil productive capacity (IPc) and topography, therefore these variables are considered together for the analysis.

Principal Component Analyses were performed (PCA) on those pairs of variable sets which showed a better degree of association in the Procrustes analyses to identify the associations between productive zones and between variables. The biplot resulting from the PCA displays information about counties and variables in the bi-dimensional space, which allows visualizing associations between county groups and variables, and identifying marginal cases.

\section{Results}

\subsection{Productive Zones}

The a priori classification based on soil, topography and production (Figure 2) was the one that yielded the smallest classification error $(4.65 \%)$ with the discriminant analysis, and was chosen for the subsequent analyses. It comprises three rural zones (agricultural, livestock and intermediate), two urban zones and a deltaic one (Figure 3).

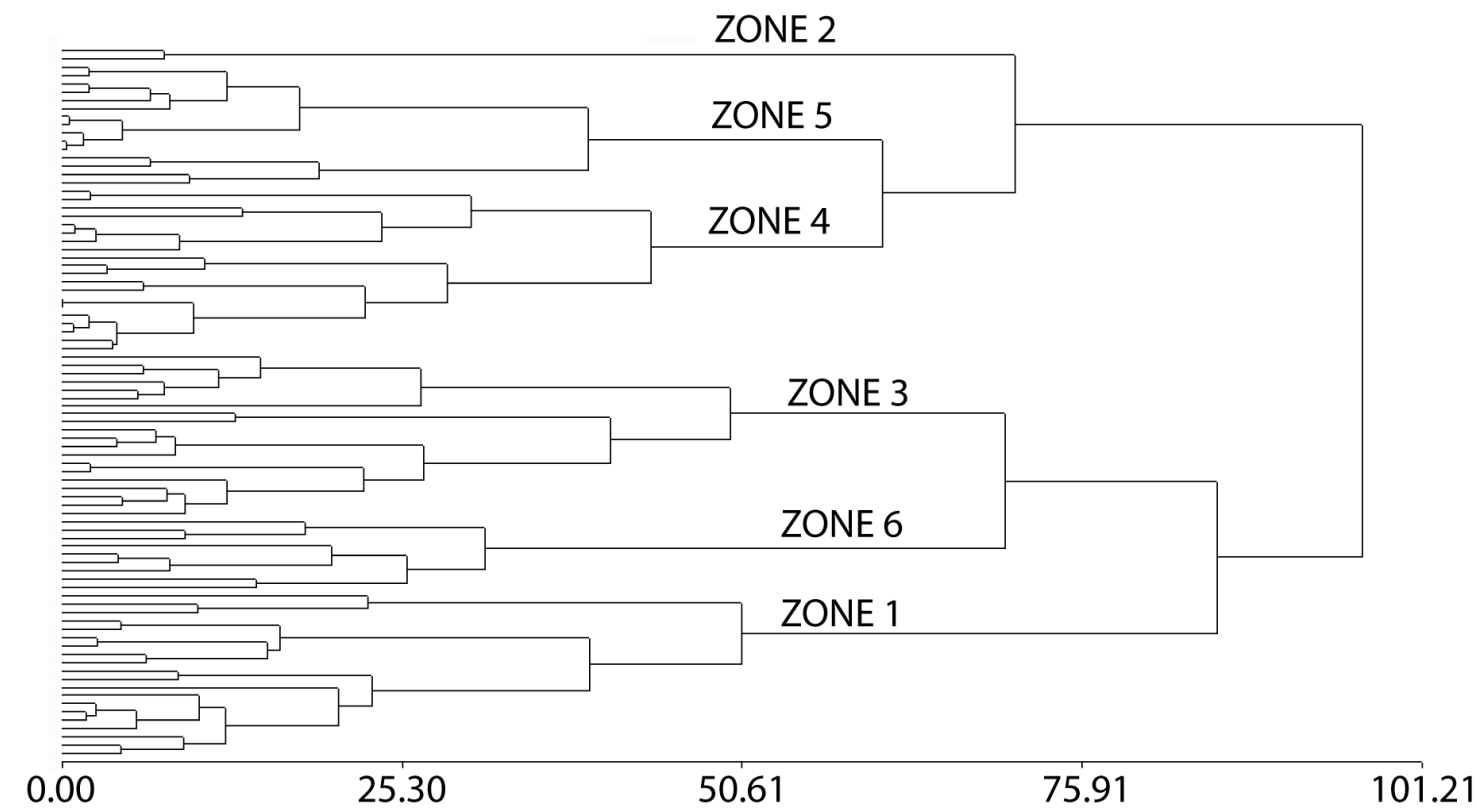

Figure 2. Productive zones classification

Cluster analysis: complete linkage and squared Euclidian distance

The metrics of patch size and density (MPS and DP), of shape (AWMSI, MPFD, AWMPFD) and of some land cover types were those of higher discrimination capacity. Most of the counties (95\%) are classified with the metrics as expected according to the chosen a priori classification (Figure 4). The six zones resulting from cluster analysis are described in terms of the variables used in the a priori classification and of the metrics differentiating them. 
Agricultural zone (Z1): It is formed by 20 counties $\left(29920 \mathrm{~km}^{2}\right)$ in the northern extreme of the studied area, the Rolling Pampa (Figure 3). This group of counties differs from the rest for having the highest percentage of high IPc soils (on average $65 \%$ of the territory) and the lowest percentage of unproductive lands $(5 \%)$, the highest percentage of hillocks (51\%) and slopes (24\%), and the highest percentage of managed land (71\%) and crop land (41\%). They are the best agricultural lands of Buenos Aires province. Together with zones 3 and 6, they have a very high percentage of the territory covered with herbaceous vegetation $(80 \%)$ and scarce urban coverage $(1.5 \%)$. The mean size of the herbaceous vegetation patches is larger than in the other groups, though it does not differ significantly from groups 3 and 6 due to the large size variability. The patches are of relatively simple geometrical shape (AWMSI=15), indicating the predominance of cultivated plots. The herbaceous vegetation forms a matrix dominated by crops, with dispersed patches of other land cover types.

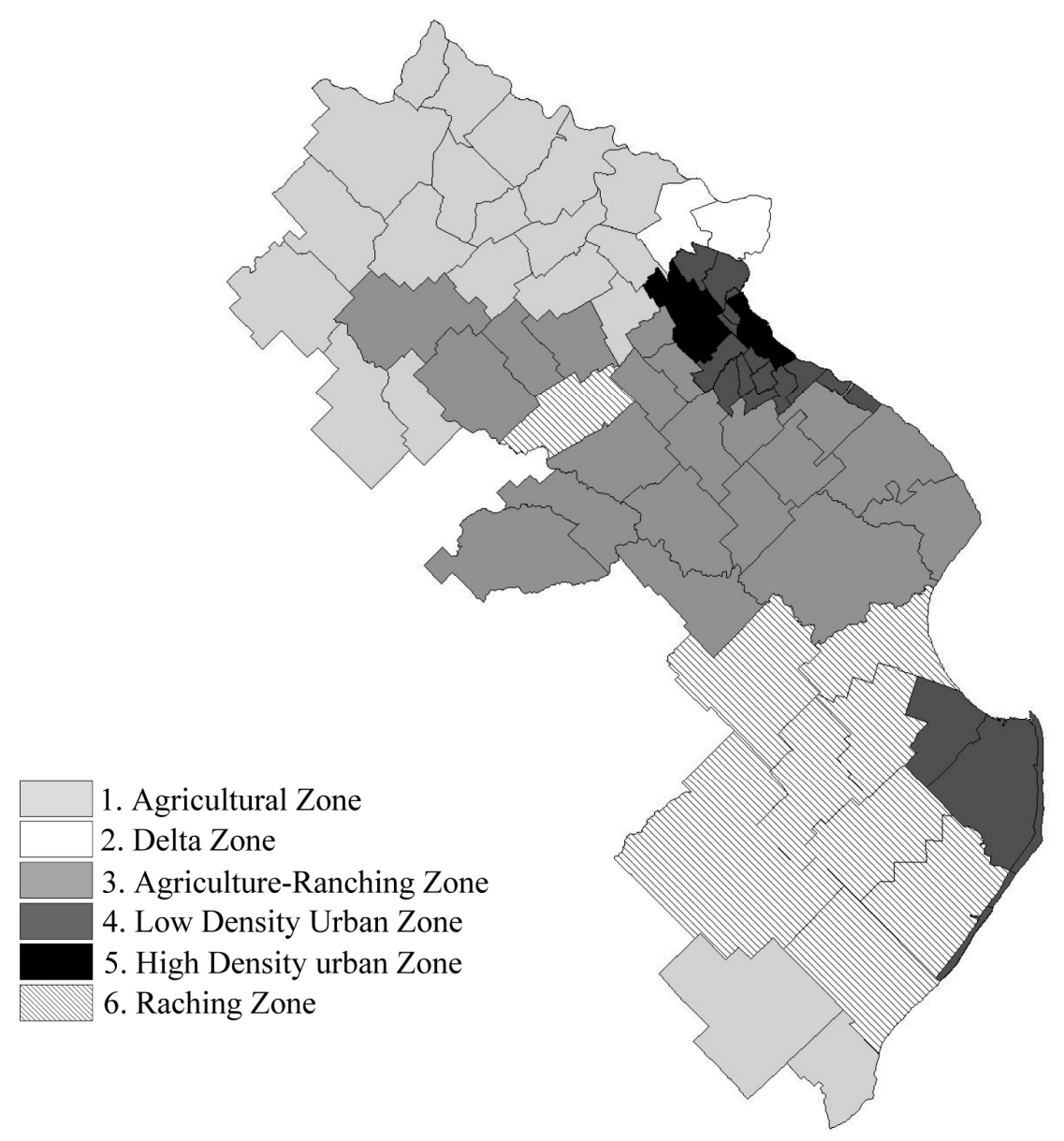

Figure 3. Production zones map (Zonification of clusters of Figure 2)

Deltaic zone (Z2): It comprises only two counties close to the La Plata River delta (Figure 3). They have on average $92 \%$ of the territory occupied by soils of very low IPc (0-30) and the non-productive topographic positions prevail, mostly low flood-prone lands. The managed surface occupies $37 \%$ of its territory, and it is the zone having the highest proportion of forest plantations ( $30 \%$ of the territory). Both counties have a large proportion of their territory in the delta islands, as evidenced by the great length of rivers ( $6 \mathrm{~km} /$ county), that separates this zone from the others. 


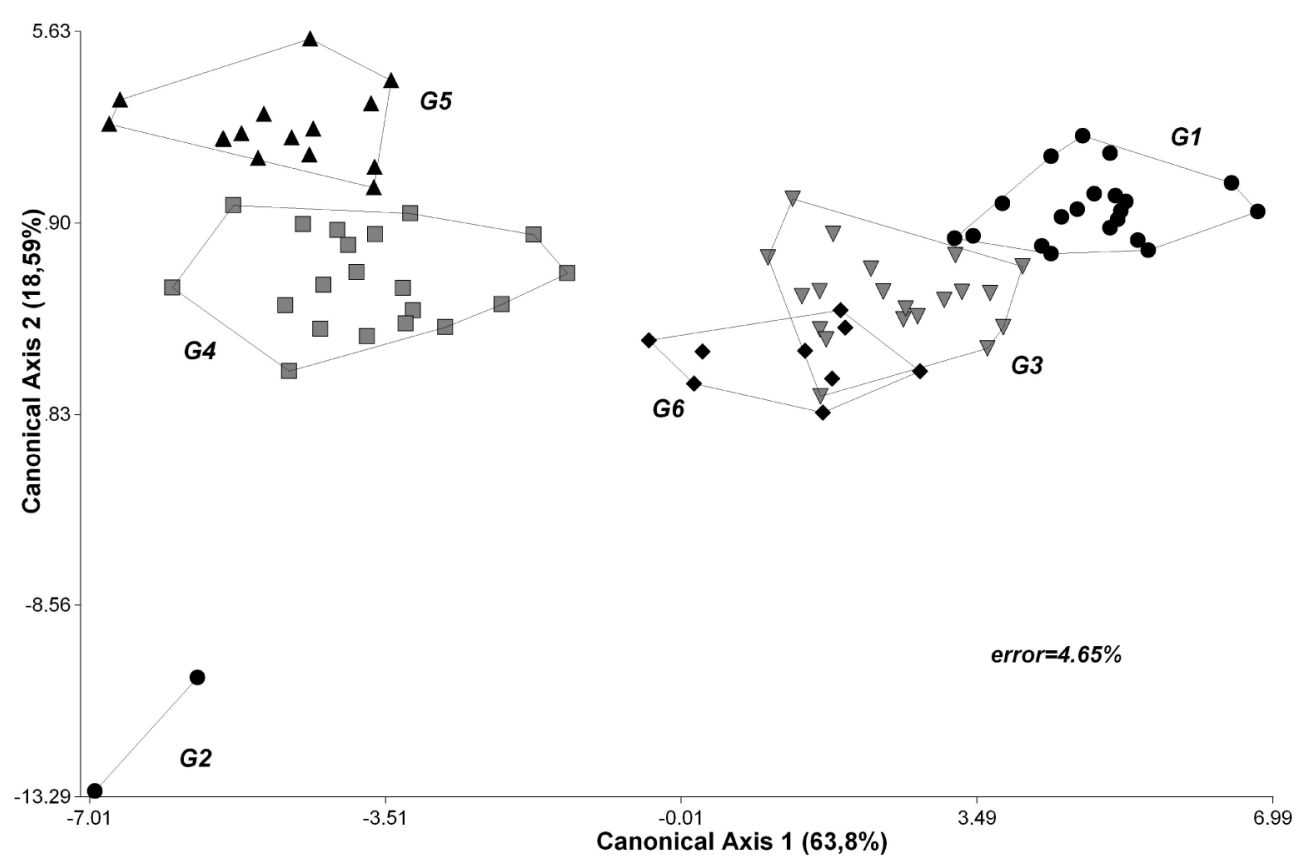

Figure 4. Discriminant function analysis plot

The a priori classification of counties is assessed by discriminant analysis with landscape metrics as predictors. G represents groups of counties in each zone

From the point of view of the spatial configuration, it differs from the other zones by the high proportion of tall grass wetlands and of tall woody vegetation ( $31 \%$ and $41 \%$ of the territory); by the large mean forest patch size, the high density of forest and wetland borders, and the great irregularity in shape of the forest patches. The wetland patches are large, but due to their great variability, the difference with those of other zones is not statistically significant. It is the typical landscape of the deltaic islands, with riparian and gallery forests, and inland wetlands and grasslands.

Intermediate agricultural-ranching zone (Z3): It comprises 20 counties in the central part of the study area, with $30390 \mathrm{~km}^{2}$ (Figure 3). Soils of medium productive capacity prevail (IPc 51-70). It differs from the rest of the zones for its flat alluvial topography that covers $13 \%$ of the territory, though the prevailing topography ( $43 \%$ of the county area) is the hillocks, like in zone 1. It is the zone with the largest average number of farms per county, though the difference with zones 1 and 6 is not statistically significant. The farm average size is the lowest in the three rural zones (1,3 and 6), and significantly lower than in zone 6 .

It differs from the other zones for the herbaceous vegetation patches, which have high mean area (102 ha/patch) and high mean border length $(7.5 \mathrm{~km} / \mathrm{patch})$. Such as in zones 1 and 6 , these are irregular in shape, especially the large patches. The total herbaceous vegetation (dense and scattered) covers most of the area $(80 \%)$. At the mosaic level, the patches are irregular, like in zone 6 . Unlike zone 1, the herbaceous vegetation forms a discontinuous matrix of grasslands, since the low herbaceous cover prevails (53\%), with very large patches of irregular shape.

Low density urban zone (Z4): This zone, of $7050 \mathrm{~km}^{2}$, is made up of a heterogeneous group of 20 counties scattered in the study area. These counties have recently undergone a remarkable conversion of lands to scattered urban use with the establishment of several gated neighborhoods, and large areas of services (malls, gas stations, hospitals, etc). Their hallmark is the high proportion ( $97 \%$ of the county area) of low productivity soils (IPc 0-30), without differing much from zone 2 in this aspect. It shares with zone 5, low values of percentage of croplands, forage-lands and forest plantations.

It differs in the spatial structure, due to the presence of forest and sandy bare soil patches; though the percentage of forest cover is relatively low, it is the only zone with forests, corresponding to pine plantations on the maritime beaches. It has a relatively high coverage (28\%) of urban lands though lower than zone 5 , but it is very similar as regards the other variables: high density of small patches at mosaic level; high density of small patches of dense 
low vegetation; high density of small patches of woody vegetation; high density of impervious patches. It also has a high percentage of herbaceous vegetation cover, but lower than in zones 1, 3 and 6 .

High density urban zone (Z5): It comprises 24 counties $\left(1,560 \mathrm{~km}^{2}\right)$ of the Metropolitan area of Buenos Aires city. It is characterized by the high proportion of unproductive lands, impermeabilized by the urban fabric, which covers on average $67 \%$ of the county area. It also has the highest value of road extension, the lowest number of farms (31 units/county) and the smallest farm mean size ( $46 \mathrm{ha}$ ). Despite the high proportion of lands with medium to high productive capacity ( $62 \%$ of the territory with IPc 5-70), these do not produce crops or livestock because they are under urban use.

Ranching zone (Z6): It occupies a portion of the Flooding Pampa included in the study area, with $26890 \mathrm{~km}^{2}$ (Figure 3). It is made up of 9 counties which are characterized by the high proportion of flood-prone lands (52\% of the county area) and plains (20\%), and by the large mean farms size (749 ha). Farm number is high (365 units per county), but it does not differ significantly from zones 1 and 3. According to INDEC (2006), it has a high percentage of natural grasslands, and according to the land cover map, the herbaceous vegetation prevails (78\%), without significant differences with zones 1 and 3 . This is the zone with highest proportion of water surfaces ( $7 \%$ of the county area).

\subsection{The Association among Variables}

The Procrustes analysis with five sets of variables showed a total consensus of $51.8 \%$, which is low and indicates that it should not be expected that the classifications based on different sets of variables end up with the same grouping. This is important for planning and management. The zonification assumes a certain level of inner homogeneity of each zone, but this does not mean that the zone is homogeneous as regards all factors operating in the landscape evolution, or in the answers to management plans. The sets of variables differ in their relative contribution to the total consensus (Table 2). Besides, the counties differ in the consensus percentage among the sets of variables, with values ranging from 27 to $71 \%$; that is, the degree of association between sets of variables depends on the county, and this indicates that there are great differences in their behavior in relation to the interactions among the studied variables.

Table 2. Contribution of each variable set to total consensus

\begin{tabular}{lcccc}
\hline \multirow{2}{*}{ Variable set } & \multicolumn{3}{c}{ Intra-set sum of squares } & \multirow{2}{*}{ Consensus (\%) } \\
\cline { 2 - 4 } & Consensus & Residual & Total & \\
\hline Landscape & 0.741 & 0.474 & 1.216 & 60.94 \\
Soils & 0.378 & 0.487 & 0.865 & 43.70 \\
Topography & 0.624 & 0.478 & 1.102 & 56.62 \\
Land use & 0.547 & 0.481 & 1.028 & 53.21 \\
Social & 0.337 & 0.488 & 0.826 & 40.80 \\
Total & 3.108 & 2.892 & 6.000 & 51.80 \\
\hline
\end{tabular}

Each set contribution is expressed as percentage of total sum of squares for the set.

The representation of the consensus by productive zones (Figure 5) shows that in three axes there are 5 zones widely spaced, and that zone 4 is overlapped with the others. In the first pair of axes (Figure 5a), zone 4 extends throughout the space and overlaps with zones 3 and 5, confirming its feature of heterogeneous group with intermediate properties between the rural and urban uses. It is also observed the overlapping of zones 3 and 6 , which are very similar due to the fact that they occupy the northern and southern portions of the Flooding Pampa. Zone 2 is represented by only one county, because the portion of islands in San Fernando county lacks social data, therefore the program eliminates it from the mathematical computation. In subsequent analyses, zone 2 is discarded. In the second pair of axes zones 3 and 6 fall apart (Figure 5b).

The Procrustes analyses by pairs of variable sets allow assessing the association among them. The results show that the percentage of total consensus is higher among pairs of variable sets (Table 3) than among the five sets simultaneously compared (Table 2), and that different pairs yield different consensus values, indicating that the associations among variables are stronger among some pairs (Table 3 ).

The highest consensus percentages are obtained between landscape metrics and topography. These results are expected since herbaceous vegetation is found in larger proportions on hillocks and slopes, while forests and wetlands concentrate on low and flood-prone lands (Figure 6). The biplot, in whose axis 1 the rural and urban 
zones fall apart, shows the association of the rural zone with the hillocks (LO), herbaceous vegetation cover and large patches, and of the urban zone, with high percentage of impervious surfaces $(\% \mathrm{U})$, high density of patches and lower proportion of hillocks and plains. Axis 2 separates the counties with high percentage of flood-prone lands, with high percentage of coverage of wetlands $(\% \mathrm{H})$ and forests $(\% \mathrm{~B})$ (Figure $6 \mathrm{a})$. In axes 1 and 3 a gradient along axis 3 is produced, with an increment in the proportion of plains and flood-prone lands from the agricultural zone in the Rolling Pampa (Z1) to the ranching zone in the Flooding Pampa (Z6) going through the transition zone (Z3) (Figure 6b).
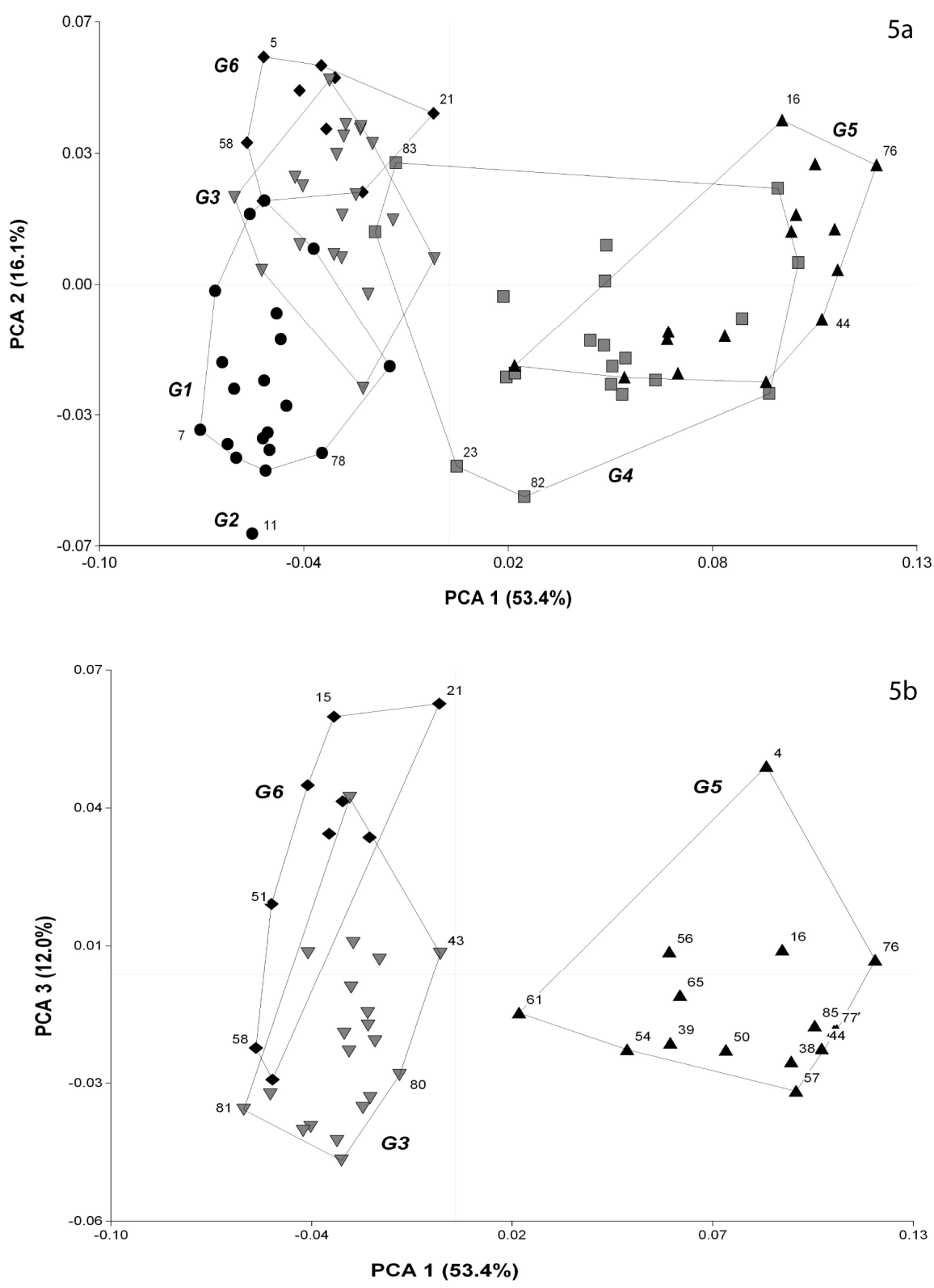

Figure 5. County consensus configuration for five variable sets

Plots of principal component axes 1 and 2 (Figure 5a), and axes 1 and 3 (Figure 5b). G represents group of counties in each zone. Counties as identified as in Figure 1. 
Table 3. Consensus between paired variable sets

\begin{tabular}{lc}
\hline Paired variable sets & \% consensus \\
\hline Soil - Land use & 68.3 \\
Landscape - Social & 72.3 \\
Landscape - Soil & 72.8 \\
Physical support - Land use & 73.4 \\
Landscape - Land use & 75.4 \\
Land use - Social & 76.0 \\
Soil - Topography & 76.5 \\
Landscape - Topography & 76.6 \\
\hline
\end{tabular}
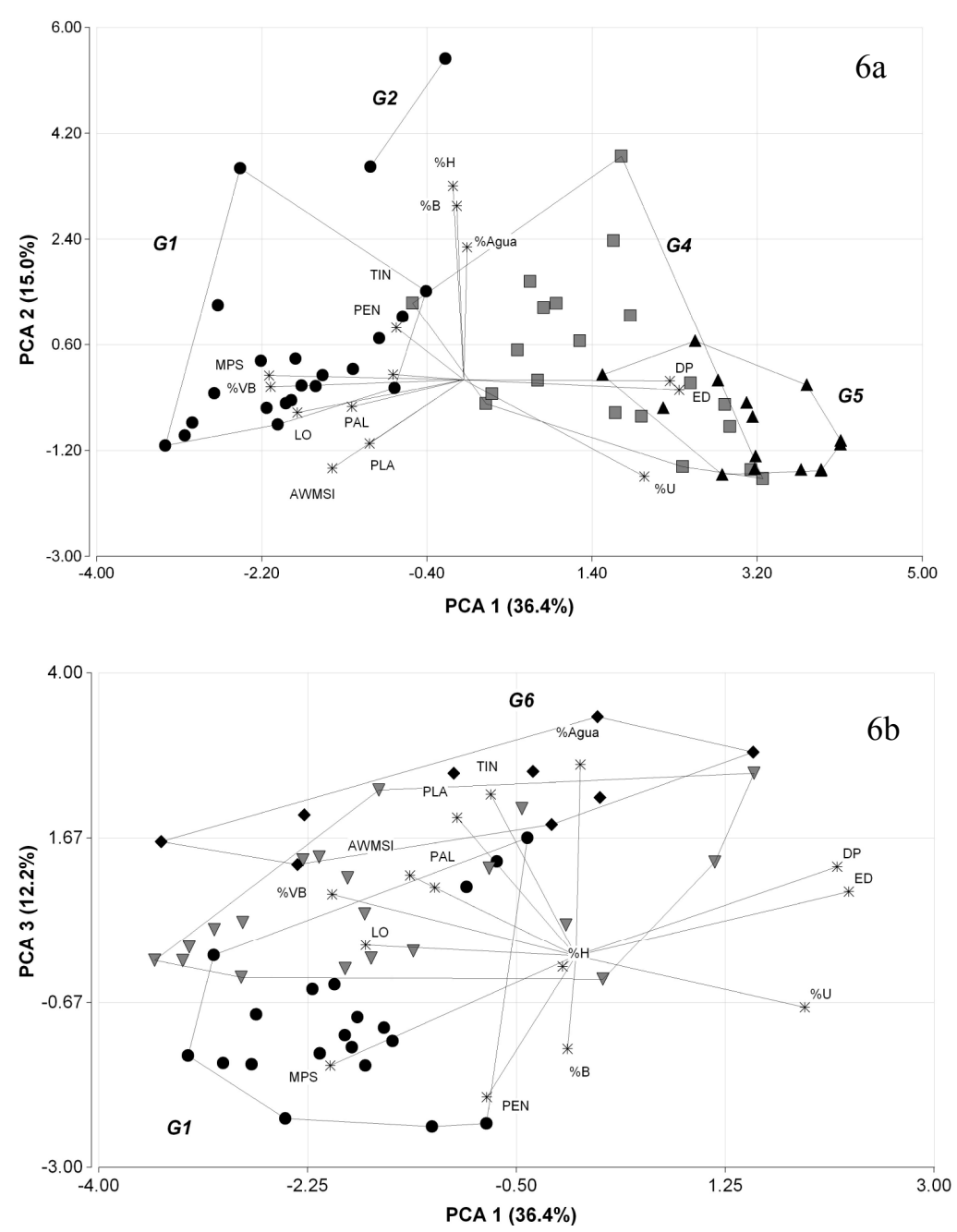

Figure 6. Association between landscape metrics and topography

Biplot of principal component axes 1 and 2 (Figure 6a), and axes 1 and 3 (Figure 6b). Variables identified as in Table 1. G: group of counties in each Productive Zone.

The most significant associations among landscape metrics and social variables (Figure 7) are the prevalence of adverse social conditions (high proportion of homes with unsatisfied basic needs, high proportion of deficient housing and homes lacking social help) with the typical landscape of urban zones (large proportion of impervious surfaces, high density of small patches). Conversely, less adverse social conditions are related to a high percentage of herbaceous coverage and very large patches. 
The biplot of the first 2 canonical axes shows the separation among the productive zones (Figure 8 ). The variables that characterize the agricultural zone are high IPc soils, the prevalence of hillocks and slopes and high proportion of crops. These variables separate $\mathrm{Z} 1$ and $\mathrm{Z} 3$ along the decreasing gradient on axis 1 . The ranching zone is associated to soils of lower IPc, abundance of flood-prone lands and large farms, which separate this zone from the intermediate zone along the increasing gradient of these variables along axis 2 . The urban zones are separated from the rural zones along axis 1 , and both urban zones become apart along axis 2 .

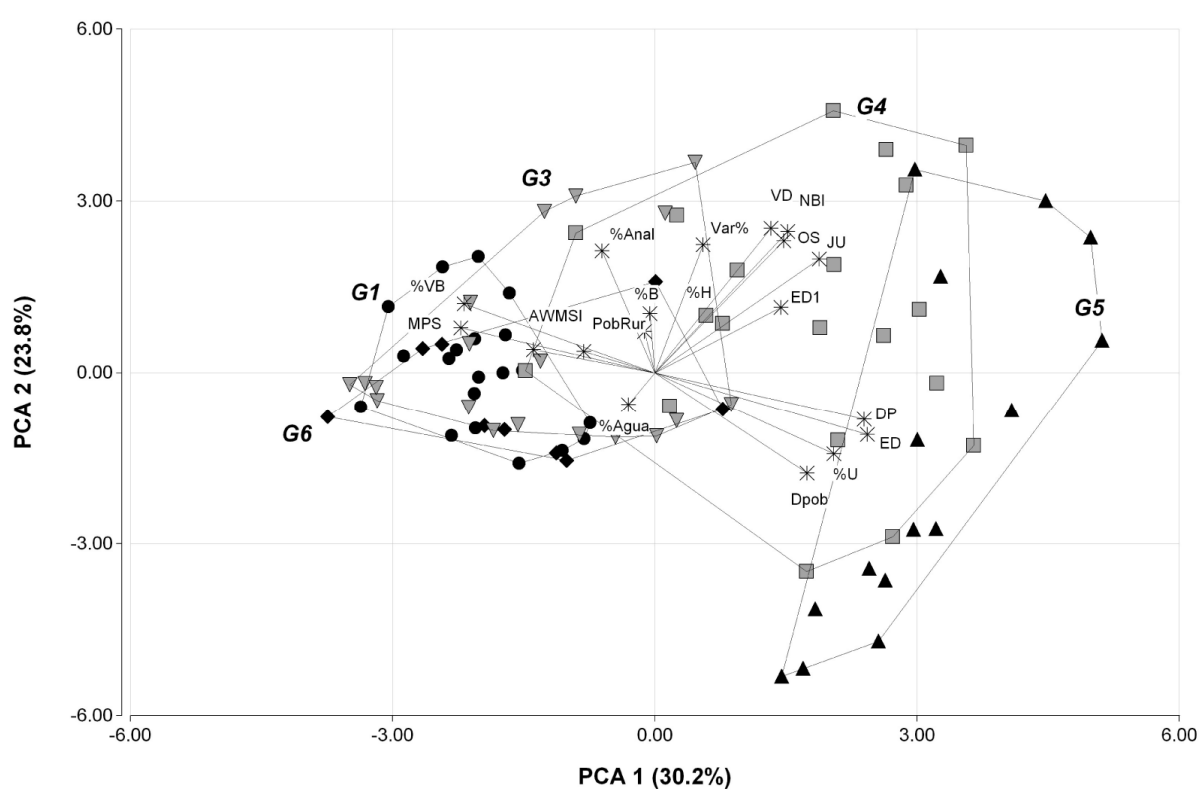

Figure 7. Association between landscape metrics and social variables

Variables labeled as in Table 1; G: group of counties in each productive zone

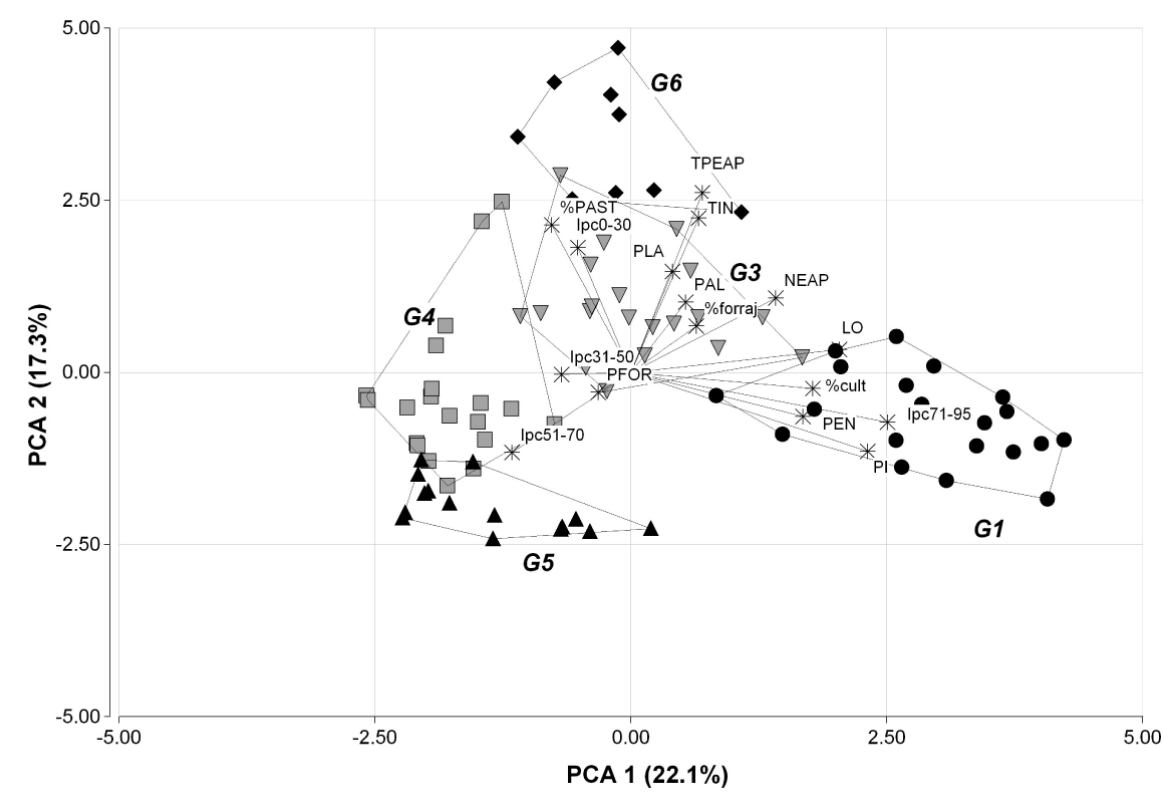

Figure 8. Association between physical support of production and land use

G: group of counties in each zone; variables labeled as in Table 1. 


\subsection{Diagnosis of the Counties}

\subsubsection{Physical Support and Land Use}

At first glance it appears that the highest consensus values occur between physical support of production and land use in zones where the agricultural and ranching activities prevail (Z1, Z3 and Z6), while lower values occur in the urban zones (Z4, Z5) (Table 4). This can be explained if we consider that urban growth has historically taken place mostly on agricultural soils (Morello et al., 2001); thus, a high consensus percentage between land suitable for production and land use cannot be expected in the metropolitan zones of Buenos Aires.

Table 4. Consensus between paired variable sets in each productive zone

\begin{tabular}{ccc}
\hline \multirow{2}{*}{ Zone } & \multicolumn{2}{c}{ \% Consensus } \\
\cline { 2 - 3 } & Physical Support-Land use & Land use-Social \\
\hline 1 & 77.9 & 72.8 \\
3 & 83.8 & 78.1 \\
4 & 72.7 & 78.6 \\
5 & 71.4 & 78.2 \\
6 & 87.3 & 87.1 \\
\hline
\end{tabular}

The differences of consensus percentage among the three agricultural and ranching zones (Z1, Z3 and Z6) point to an increasing gradient from North to South, which is related to the landscape evolution in response to the proximity to the metropolitan area and their impacts on neighboring rural areas. Zone 6, the furthest zone from the capital city, shows a higher consensus; zone 3, of interface between ranching and agricultural zones, shows intermediate values of consensus. Zone 1 has the lowest consensus percentages, since it is undergoing urban expansion caused by gated neighborhood development as scattered perforations (Forman, 1995) in the agricultural matrix. Here there is a mismatch between land suitability and land use, though not so intense as in zone 4 (Table 4).

These observations are confirmed at county level. Counties of lower consensus in the agricultural zone (Z1) are those that are in contact with the urban zone (Z5), those that have suffered processes of exurbanization since the 1990s, and those which are crossed by important routes or highways, another driver of agricultural lands change. The rest of the counties show consensus values higher than the average for the zone. In agricultural (Z1) and ranching (Z6) zones, most of the counties have consensus values above the corresponding average, while the intermediate zone (Z3) has consensus values lower than the average in most of the counties. The counties of highest consensus are those that have better agricultural soils and lack of exurbanization (Matteucci y Morello, 2009), or that are far from the urban borders. In the ranching zone (Z6), the counties of lowest consensus are in the neighborhood of tourist areas under full process of urban expansion.

In the low density urban zone (Z4) most of the counties have consensus values higher than the average, although the values are lower than those of the rural zones. The lowest values are those of the counties with greater urban development, in contact with the dense urban zone (Z5). The counties of highest consensus are found in the external borders, in contact with zones 3 and 1 . In the dense urban zone, most counties have consensus values lower than the average, indicating a mismatch between land suitability and land use.

\subsubsection{Land Use and Social Conditions}

The ranching zone (Z6) is that of highest consensus between land use and social conditions (Table 4), repeating the pattern described above; that is, the counties furthest from the urban border show a better adjustment between land use and social conditions. No explanation can be found for the low consensus values of some counties in which land use seems to agree with land suitability. The situation may be due to a bad administration by the local government. The counties furthest from the urban border show higher percentages of consensus between land use and social conditions.

Agricultural zone (Z1) has the lowest consensus between land use and social conditions (Table 4), showing an unstable system in continuous change. The counties of highest consensus show the proper land use reflected in their good social conditions, and most of them are far from the urban border. An interesting example is a county that, despite being surrounded by others with extensive exurbanization, shows social welfare due to its long agricultural and ranching tradition that caused a shift to rural tourist activities, maintaining the concordance between land use and land suitability. 


\section{Discussion}

The prediction stated in the introduction is fulfilled in some cases but not in others. At county level, all the zones present the 4 possible combinations of adjustment between physical support and land use, and their positive or negative consequence on the social conditions. The multidimensional space of consensus between the variable sets Physical support-Land use, and Land use-Social conditions, can be classified in 4 cells (Table 5), where the consensus percentages are divided arbitrarily in high and low, whether the value is above or below the average consensus percentage for the group. Cells 1 and 4 support the hypothesis that land use is reflected on the social conditions, either because of social welfare as a consequence of proper land use, or because of the adverse social conditions associated to the improper allocation of land to uses for which it is not suitable. Cells 2 and 3 do not support the hypothesis, either because of social indicators of poverty despite the consistency between land use and land suitability, or because of social welfare in presence of improper land use (Table 5).

Table 5. Sustainability in bidimensional space of consensus between paired variable sets

\begin{tabular}{|c|c|c|c|}
\hline & & \multicolumn{2}{|c|}{ Land use-Social variables } \\
\hline & & high consensus & low consensus \\
\hline \multirow{2}{*}{$\begin{array}{l}\text { Physical } \\
\text { support - } \\
\text { Land use }\end{array}$} & $\begin{array}{l}\text { high } \\
\text { consensus }\end{array}$ & $\begin{array}{l}\text { 1. Land use adjusted to land suitability is } \\
\text { reflected in good social conditions }\end{array}$ & $\begin{array}{l}\text { 2. Land use adjusted to land suitability; } \\
\text { however, poor social conditions }\end{array}$ \\
\hline & $\begin{array}{l}\text { low } \\
\text { consensus }\end{array}$ & $\begin{array}{l}\text { 3. Land use not adjusted to land suitability; } \\
\text { however good social conditions }\end{array}$ & $\begin{array}{l}\text { 4. Land use not adjusted to land } \\
\text { suitability is reflected in poor social } \\
\text { conditions }\end{array}$ \\
\hline
\end{tabular}

The counties of productive zones 1, 3 and 6, are assigned to cells depending on whether the consensus percentage is higher or lower than the average value for the group of counties that make up each zone. A matrix showing the quantity and percentage (between brackets) of counties of each productive zone in each cell is obtained (Table 6). Out of the 49 counties of the rural zones (Z1, Z3 and Z6), 67\% is in stable conditions; that is, land use is reflected on the social conditions (cells 1 and 4 in Table 5), while 14\% has bad social conditions (high values of NBI) even though land use is in agreement with land suitability, and $18 \%$ shows good social conditions in the presence of low concordance between land use and land suitability.

With the available information it is not possible to establish the cause/effect relationships between proper land use and bad social conditions, or improper land use and good social conditions. The hypothesis is that in the former the municipal management is not adequate, and this deserves a study which would enable assessing the efficiency in the allocation of resources according to the management plans in force. It would be a feasible study as there is a wide and varied collection of counties for comparing cases.

The county categorization according to productive and social conditions in the four cells shows that the management solutions cannot be the same for all counties. Those counties located in cell 1 are those of lower risk, and could remain unchanged in the present scenario. In counties assigned to cell 2 , the improvement in social conditions should be emphasized by redistributing the resources in a different way. A study to identify the causes leading to the current situation is required. Counties in cell 3 should improve land use assignment, because they show a high vulnerability degree; even though the social conditions are good, the low consensus between physical support and land use shows a mismatch that could result in social deterioration. The counties in the fourth cell are the most vulnerable, since they show a mismatch between both pairs of variable sets; in the first place, land use assignment should be improved. Out of the 15 counties located in the fourth cell, eight are forming a new urban fringe around the Buenos Aires/La Plata metropolitan areas, and two are in contact with maritime tourist zones in expansion. The other 3 are separated from the dense urban area: however either they have already undergone exurbanization or they are close to counties with gated neighborhoods. The 15 counties are crossed by highways or national routes. 
Table 6. Sustainability level of the human-natural system in each the rural productive zones

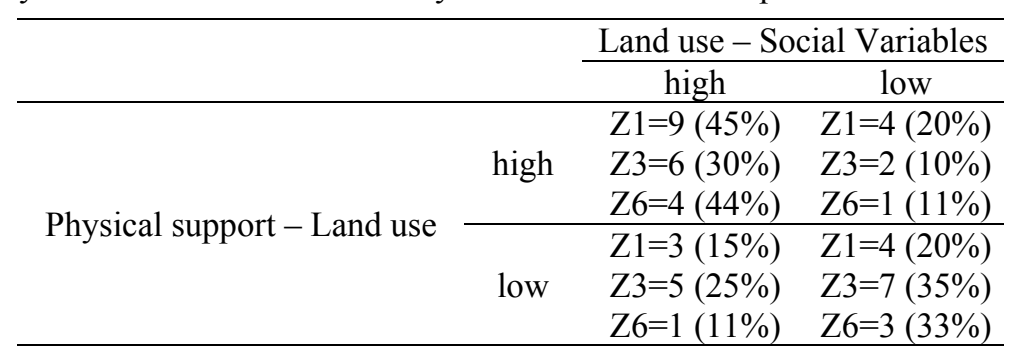

Number and percent of total counties in each sustainability level per productivity zone.

The Procrustes analysis is becoming a promising integration tool to understand the interactions between social, natural and productive subsystems in complex systems. The method has allowed generating a bi-dimensional indicator of sustainability (Matteucci \& Pla, 2010).

\section{Conclusions}

The results of the present work show a variable degree of unsustainability in the human-natural system in the study area. The vulnerability of the counties is greater in the proximity of the metropolitan area, showing there a higher risk of agricultural lands conversion to urban use. At a larger spatial scale, the vulnerability decreases from North to South, and increases again in the proximity of the tourist counties of the Atlantic coast. The fate of the counties depends on the political decisions of the National State, who is responsible for formulating the national development plan, and on the corresponding municipalities, who have the mandate and capacity for implementing the projects at local level. Inaction at this time will result in the deterioration of the economic and social situation.

In previous works, the importance of the environment conditions in the development of Pampean systems has been pointed out (Morello \& Matteucci, 1997), and this is valid in the analysis of the agricultural evolution at regional level. However, there are many local factors that operate at smaller temporal and spatial scales, and that affect land use patterns, especially in relation to urban growth. These factors and their interactions vary in space and give rise to variations among and within productive zones.

The variable sets chosen for the current work do not cover all the situations. Cultural indicators are required to allow explaining some of the observations. The fact that in some counties there is no evidence of a tendency towards urbanization, despite being close to the urban border or surrounded by counties with a great gated neighborhood development may be due to cultural peculiarities of their population, including traditions, habits, or a conscious selection of the desired lifestyle.

This work does not include an analysis of the Master Plans of each county, which could also be related with the patterns of growth and evolution of the socio-economic activities. Finally, it would be important to incorporate information about land ownership and industrial, commercial and service activities.

\section{Acknowledgements}

This research was financed by the Agencia Nacional de Promoción Científica y Tecnológica de Argentina (PICT 13-8481), and the Consejo Nacional de Investigaciones Científicas y Técnicas (PIP 012201, 2011-2013), Argentina.

We would like to thank Dr. Laura Pla for her contributions in the multi-varied statistical analyses; to the Comisión Nacional de Actividades Espaciales for the donation of satellite images; to the Instituto Geográfico Militar, SIG250, for the donation of digitalized topographic sheets, and to the Instituto Nacional de Estadística y Censos for the digitalized map of the counties of Buenos Aires Province.

\section{References}

Di Georgio, A., \& Jansen, L. J. M. (2000). Land Cover Classification System (LCCS): Classification Concepts and User Manual. Part One: Classification Concepts. Environment and Natural Resources Service, GCP/RAF/287/ITA Africover - East Africa Project and Soil Resources, Management and Conservation Service. Food and Agriculture Organization of the United Nations, Rome. Retrieved from http://www.fao.org/docrep/008/y7220e/y7220e06.htm\#bm06

Elkie, P. C., Rempel, R. S., \& Carr, A. P. (1999). Patch Analyst User's Manual. Ontario Ministry of Naturural Resources, Northwest Sci. \& Technol. Thunder Bay, Ont. TM-002. 16 pp + Append. 
Forman, R. T. T. (1995). Land Mosaics. The ecology of landscapes and regions. Cambridge University Press.

Gower, J. C. (1975). Generalized procrustes analysis. Psychometrika, 40, 33-51. http://dx.doi.org/10.1007/BF02291478

Gunderson, L. H., \& Holling, C. S. (2002). Panarchy. Undestanding transformations in human and natural systems. Washington, Covelo, London: Island Press.

Holling, C. S. (1973). Resilience and stability of ecological systems. Annual Review of Ecology and Systematics, 4, 1-24. http://dx.doi.org/10.1146/annurev.es.04.110173.000245.

INDEC. (2002). Censo Nacional de población, hogares y viviendas 2001. Provincia de Buenos Aires. Ministerio de Economía, Secretaría de Política Económica, Instituto Nacional de Estadística y Censos (National Institute of Statistics and Censuses), Buenos Aires. Retrieved from http://www.indec.mecon.ar/

INDEC. (2006). Censo Nacional Agropecuario 2002. Instituto Nacional de Estadísticas y Censos, Ministerio de Economía, Secretaría de Política Económica, Instituto Nacional de Estadística y Censos (National Institute of Statistics and Censuses), Buenos Aires. Retrieved from http://www.indec.mecon.ar/

Infostat. (2004). InfoStat, versión 2004, Manual del Usuario. Grupo InfoStat, FCA, Universidad Nacional de Córdoba. Primera Edición, Editorial Brujas, Córdoba. Argentina. Retrieved from http://www.infostat.com.ar

Jackson, D. A., \& Harvey, H. H. (1993). Fish and benthic invertebrates: community concordance and community-environment relationships. Canadian Journal of Fisheries and Aquatic Sciences, 50, 2641-2651. http://dx.doi.org/10.1139/f93-287

King, J. R., \& Jackson, D. A. (1999). Variable selection in large environmental data sets using principal $\begin{array}{lllll}\text { components } & \text { analysis. } & \text { Environmetrics, } & 10, & 67-77 .\end{array}$ http://dx.doi.org/10.1002/(SICI)1099-095X(199901/02)10:1<67::AID-ENV336>3.0.CO;2-0

Maccarini, G. D., \& Baleani, O. (Coordinadores). (1995). Atlas de Suelos de la República Argentina. Base cartográfica digitalizada. Fundación ArgenINTA, CIRN Instituto de Suelos INTA, Aeroterra, Buenos Aires.

Matteucci, S. D., \& Morello, J. (2009). Environmental consequences of exurban expansion in an agricultural area: the case of the Argentinian pampas ecoregion. Urban Ecosystems, 12, 287-310. http://dx.doi.org/10.1007/s11252-009-0093-z

Matteucci, S. D., \& Pla, L. (2010). Procrustes analysis as a tool for land management. Ecological Indicators, 10, 516-526. http://dx.doi.org/10.1016/j.ecolind.2009.09.005

Morello, J., \& Matteucci, S. D. (1997). El modelo agrícola del núcleo maicero como sistema complejo. En: J. Morello y O. T. Solbrig (compiladores) Argentina granero del mundo: hasta cuándo?, Orientación Gráfica Editora, S.R.L., Buenos Aires. Pp. 201-231.

Morello, J., Matteucci, S. D., \& Rodríguez, A. (2003). Sustainable development and urban growth in the Argentine pampas region. Annals of the American Academy of Political and Social Science, 590, 116-130. http://dx.doi.org/10.1177/0002716203256901

SAGyP-INTA. (1989). Mapa de los suelos de la Provincia de Buenos Aires. Proyecto PNUD ARG 85/019. Secretaría de Agricultura, Ganadería y Pesca (SAGyP) e Instituto Nacional de Tecnología Agropecuaria, Buenos Aires.

World Resources Institute. (1996). The urban environment. En: World Resources, a Guide to the Global Environment. Washington, DC: World Resources Institute. 